\title{
Redistribution and Desorption Kinetics of Some Heavy Metals in Biosolids Treated Soils Amended with Water Treatment Residual Nanoparticles
}

\author{
Mohamed L. Moharem ${ }^{1}$
}

\begin{abstract}
The study was designed to demonstrate the effect of water treatment residual naoparticles amendments for $0.3 \%$ biosolids treated calcareous and sandy soils on $\mathrm{Cu}$, $\mathrm{Pb}$, and $\mathrm{Ni}$ fractions change and release during 60 days incubation period; included five wetting drying cycles regime. The redistribution of studied metals fractions for control soil (0\%WTR) depended on soil and metal type. There was a pronounced decrease in metal-residual fraction at the end of the incubation period (60 days); while other fractions were occupied with these residual fraction- released metals. Application of nWTR to both soils substantially reduced the non-residual fractions (NORS) of $\mathrm{Cu}$ and $\mathrm{Ni}$ and simultaneously increased residual (RS) both metals fractions. Furthermore, both $\mathbf{P b}$ oxides and RS fractions were increased as a result of nWTR addition. The metals forms transformation for nWTR amended soils as the incubation time prolonged from 30 to 60 days was studied. The $\mathrm{Cu}$-forms transformation remained relatively unaltered with slightly increase of $\mathrm{RS} \mathrm{Cu}$ versus decrease of exchangeable and carbonate $\mathrm{Cu}$. With respect to $\mathrm{Pb}$ and $\mathrm{Ni}$, residual fraction was increased significantly and this increase was arisen from either the decrease of all fractions of Ni- NORS or $\mathrm{Pb}$-organic fraction. The amount of desorbed $\mathrm{Cu}, \mathrm{Pb}$, and Ni from both soils using DTPA extraction was significantly decreased after application of nWTR within the five wetting drying cycles. All the kinetic data were well expressed using both intraparticle diffusion and Elovich models due to the high coefficient of determination $\left(R^{2}\right)$ and low standard error (SE) values. The final results indicate the ability of nWTR to reduce heavy metals mobility in biosolid treated calcareous and sandy soils.
\end{abstract}

Key words: Biosolid, water treatment residual naoparticles, incubation period, fractionation, desorption kinetic.

\section{INTRODUCTION}

The remarkable increase in global population and also the prompt outgrowth of industrial and agricultural activities leaded to solid wastes such as biosolids to increase rapidly (Shao et al. 2015). These biosolids are defined as heterogeneous substances of biological wastes produced from sewage treatment procedures that contains organic/ inorganic substances, bacteria, and colloid particles. Inappropriate disposal of biosolids such as incineration, land filling (Marguí et al., 2016; Kominko et al., 2017) and sea dumping can lead to several environmental troubles such as surface and groundwater contamination, land degradation, and food chain contamination (Wong, 1995; Singh and Agrawal, 2008). From the environment point of view, agricultural land application of biosolids will be a best choice preference over the other disposal methods (Kacprzak et al. 2017); since it can produce significant benefits concerning soil fertility and plant growth (Herzel et al. 2015; Rigby et al. 2015; Grobelak et al. 2017). Although the high advantages of biosolids-agricultural application, the high content of certain heavy metals in biosolids may diminish its application (Turkdogan et al., 2003; Wang et al., 2003); since these metals may cause human health hazardous impact -via plant uptakedue to their accumulation in agricultural soils (McLaughlin et al. 2006; Wang et al. 2005). Therefore, the mobility and bioavailability of heavy metals (HMs) in biosolids amended soils should be minimized which can be properly achieved through well understanding the behavior of HMs under realistic conditions of contaminated soils.

Fate of heavy metals in soil environment are mainly depends on removal of metals from the soil solution towards solid surfaces (sorption), desorption of the metal from the soil particle to the soil solution, and precipitation-dissolution reactions of the metal (Sposito, 1989; Sparks, 2003). Furthermore, redistribution of metals among solid-phase components during different residence time can directly control metal mobility and toxicity in soils (Davies et al., 2003;Wu et al., 2006 ).

Furthermore, the physical, chemical, and biological processes occurring in irrigated soils could be strongly affected by the wetting-drying cycles (Han et al., 2001). This water periodic regime can simulate the real field irrigation in the semi-arid soils (Khodaverdiloo et al., 2012). It plays a vital function in governing the mobility of heavy metals and hence controls their possibility danger in contaminated soils. Furthermore, heavy metals redistribution and re-desorption could be affected (Zheng and Zhang, 2011; Yang et al., 2019 ).

The remediation technique of contaminants -such as HMs- that aims to decrease the concentration of dissolved contaminants by sorption and or precipitation knows as chemical immobilization (Basta and McGowen, 2004); which can be achieved by addition of organic/inorganic amendments to reduce contaminant 
solubility or bioavailability to the plants (Guo et al., 2006; Hashimoto et al.,2009). Using low cost waste materials as an immobilizing agents in $\mathrm{HMs}$ contaminated soils have been -recently- in growing interest (Bolan et al., 2014; Lu et al., 2017; Moharem et al., 2011\& 2016; Moharem, 2016). One of such materials is drinking water treatment residuals (DWTR). It is a waste that produces during drinking water treatment and contains aluminum salts for coagulation. DWTRs have a similar structure of noncrystaline aluminum hydroxide that behaves similar to amorphous Al soil mineral forms (Tisdale et al., 1985). These wastes have a multitude sorption surface sites due to their large surface area and microporous nature (Makris et al., 2004); consequently reuse of DWTR for sequestering heavy metals in contaminated soils has been newly condensed (Sarkar et al., 2007; Hovsepyan \& Bonzongo, 2009; Moharem et al., 2013; Moharem, 2012; Elkhatib \& Moharem, 2015). Furthermore, increasing the sorption capacity of these wastes has been recently achieved by converting bulk DWTR to Nanoscale water treatment residual (nWTR) by precision milling (Elkhatib et al., 2015a). Despite of the successful proof of reusing nWTR in land application and wastewater (Moharem, et al., 2019; (Moharem, et al., 2019; Elkhatib et al., 2017, 2018, 2019), few studies regarding heavy metals stabilization in biosolid-added soils are revealed. Furthermore, information in the literature concerning kinetic release-modeling of $\mathrm{HMs}$ in nWTR-treated soils through different wetting-drying cycles is missing; since such information is critical in evaluating the expediency of nWTR as soil amendment. Therefore, this study aims to evaluate the effect of nWTR addition to Egyptian biosolids amended calcareous and sandy soils on : (1) redistribution of geochemical forms for $\mathrm{Cu}, \mathrm{Pb}$, and $\mathrm{Ni}$ after 12 days and 60 days incubation period, and (2) metals releasemathematically expressed- within five wetting (field capacity) drying cycles regime.

\section{MATERIALS AND METHODS}

\section{Soils and water treatment residuals nanoparticles (nWTRs)}

Two soil samples differed in texture and calcium carbonate content were utilized. Sandy soil (Typic Quart zipasmments) was collected from Elbostan $80 \mathrm{Km}$ south west Alexandria and calcareous soil (Typic Calciorthids) from El-Nahda $40 \mathrm{Km}$ south west Alexandria. Soil samples were air-dried, passed through a 2-mm sieve and stored in plastic bags for later use. The drinking water treatment residuls (DWTRs) were collected from the Drinking Water Treatment Plant in Kafr El-Dawar, El-bahera governorate Egypt, and air- dried prior to their use (Makris and Harris, 2005). Selected chemical and physical properties of soils and DWTRs are shown in Table1. Soil electrical conductivity (EC) and $\mathrm{pH}$ were determined in the saturated soil paste extract and in 1: 2.5 suspension of DWTRs (Richards, 1954). The bioavailable $\mathrm{Cu}, \mathrm{Pb}$, and Ni were extracted by DTPA (Lindsay and Norvell, 1978) and measured by atomic absorption spectroscopy (contrAA 300). ). Soil organic matter content was estimated by the method of Walky and Black (Nelson \& Sommers, 1982), total carbonate equivalent was determined by the calcimiter method (Nelson, 1982), and cation exchange capacity was measured by the method of Rhoades (1982). Particle size distribution analysis was determined by the hydrometer method (day, 1965). Total amount of Al in DWTRs was measured according to Ross and Wang (1993) method using acid ammonium oxalate.

\section{Biosolids}

The stabilized wastewater solids under controlled aerobic conditions that called biosolids were collected from Alexandria waste water treatment plant (N9). Table 1 illustrates chosen chemical properties of the biosolids. Aqua regia method were used for heavy metals total concentrations determination (Esakku, et., 2005; Shrivastava and Banerjee, 1998) by atomic absorption spectroscopy (contrAA 300). Total amount of organic matter were measured according to Walky and Black method (Nelson \& Sommers, 1982).

\section{Preparation of WTR nanoparticles (nWTR)}

The nWTR were obtained from bulk WTR utilizing Fritsch planetary mono mill approach as described by Elkhatib et al. (2015a). The characteristics and element contents of nWTR were examined employing transmission electron microscopy, $\mathrm{x}$-ray diffraction, scanning electron microscopy with energy dispersive $\mathrm{X}$ ray (SEM-EDX; INCAx-Sight model 6587, Oxford Instruments, UK) and autosorb iQ surface area analyser (Quantachrome, USA),(Elkhatib et al., 2015b).

\section{Incubation Experiment}

Three nWTR rates $(0,0.1,0.3 \%)$ and one rate of WTR $(2 \%, w / w)$ in addition to $3 \%$, w/w biosolids were added to $1 \mathrm{~kg} /$ soil, in the laboratory, to represent the field addition rates for DWTRs and biosolids. Soil samples were well mixed with biosolids and /or DWTRs. Hereafter, the mixture was incubated for 60 days in five wetting-drying cycles regime. Each cycle was continued for 12 days; the first 2 days was for adding water -at field capacity- while the 10 days rest was for air-drying. Each treatment was conducted in 
Table1. Selected chemical and physical properties of the studied soils, DWTR, and biosolid

\begin{tabular}{cccccc}
\hline Characteristics & units & Calcareous & Sandy & DWTR & Biosolids \\
\hline $\mathrm{pH}^{*}$ & & $8.33 \pm 0.08$ & $8.26 \pm 0.06$ & $7.45 \pm 0.11$ & $6.72 \pm 0.09$ \\
$\mathrm{EC}^{*}$ & $\mathrm{dS} \mathrm{m}^{-1}$ & $4.56 \pm 0.12$ & $3.19 \pm 0.06$ & $1.67 \pm 0.18$ & $8.12 \pm 0.07$ \\
$\mathrm{Clay}$ & $\%$ & $22.10 \pm 3.55$ & $5.00 \pm 1.18$ & - & - \\
$\mathrm{Silt}$ & $\%$ & $7.80 \pm 1.63$ & $2.500 \pm 2.46$ & - & - \\
$\mathrm{Sand}$ & $\%$ & $70.10 \pm 4.45$ & $92.50 \pm 6.17$ & - & - \\
Texture & & $\mathrm{S} \mathrm{C} \mathrm{L}$ & $\mathrm{S}$ & - & - \\
$\mathrm{OM}$ & $\%$ & $1.5 \pm 0.67$ & $0.4 \pm 0.06$ & $5.70 \pm 1.25$ & $492 \pm 2.87$ \\
$\mathrm{CaCO} 3$ & $\%$ & $22.4 \pm 0.79$ & $3.6 \pm 0.18$ & $3.48 \pm 0.19$ & - \\
$\mathrm{CEC}$ & $\mathrm{cmol} \mathrm{kg}^{-1}$ & $15 \pm 0.41$ & $6 \pm 0.69$ & $34.78 \pm 2.06$ & - \\
Total Al & $\mathrm{g} \mathrm{kg}^{-1}$ & - & - & $38.01 \pm 1.87$ & - \\
Total metal & $\mathrm{mg} \mathrm{kg}^{-1}$ & & & & \\
$\mathrm{Cu}$ & & $0.198 \pm 0.12$ & $0.218 \pm 0.22$ & $2.87 \pm 0.13$ & $385.93 \pm 5.65$ \\
$\mathrm{Ni}$ & & $0.159 \pm 0.09$ & $0.393 \pm 0.14$ & $4.63 \pm 0.23$ & $26.83 \pm 1.34$ \\
$\mathrm{~Pb}$ & & $0.905 \pm 0.11$ & $0.712 \pm 0.13$ & $3.06 \pm 0.12$ & $219.24 \pm 4.87$ \\
Soluble Al & $\mathrm{mg} \mathrm{kg}^{-1}$ & - & - & $1.80 \pm 0.14$ & - \\
DTPA-extractable & $\mathrm{mg} \mathrm{kg}^{-1}$ & & & & \\
metal & & $0.95 \pm 0.0 .05$ & $0.19 \pm 0.03$ & $1.20 \pm 0.05$ & $28.4 \pm 1.69$ \\
$\mathrm{Cu}$ & & $0.083 \pm 0.04$ & $0.124 \pm 0.02$ & $2.49 \pm 0.08$ & $2.7 \pm 0.19$ \\
$\mathrm{Ni}$ & & $0.57 \pm 0.04$ & $0.41 \pm 0.04$ & $1.58 \pm 0.06$ & $12.8 \pm 0.34$ \\
$\mathrm{~Pb}$ & & - & $470.00 \pm 2.18$ & $250 \pm 2.87$ \\
$\mathrm{WHC}$ & $\mathrm{g} \mathrm{kg}^{-1}$ & - & &
\end{tabular}

EC - electrical conductivity; OM - organic matter; CEC - cation exchange capacity;

WHC - water holding capacity; C - Clay; SCL - sandy clay loam; S - sandy;

$\mathrm{pH}^{*}$ was measured in 1:2 $\mathrm{H}_{2} \mathrm{O}$ extract; $\mathrm{EC}^{*}$ was measured in soil paste

replicated pots. Subsamples were taken periodically after 15 days of each cycle for DTPA extraction; while subsamples were taken after the first (12 days) and the fifth (60 days) cycles for sequential extraction technique. In each cycle, soils through the first 2 days of incubation were wrapped to avoid evaporation, while the following 10 days the soils were permitted for airdrying at $25^{\circ} \mathrm{C}$. Before sampling, the soil was blended totally to maintain samples similarity.

\section{DTPA and sequential extractions}

The bioavailable form of heavy metals was determined in incubated soils using DTPA extraction according to Lindsay and Norvell, 1978 and measured by atomic absorption spectroscopy (contrAA 300).

Furthermore, sequential extraction technique was exercised to fractionate heavy metals in incubated soils that advanced by Tessier et al. (1979). Each heavy metal- fractions was operationally defined as follows: exchangeable fraction (extractable with $1.0 \mathrm{M} \mathrm{MgCl}_{2}$ at $\mathrm{pH} 7$ ); carbonate bound fraction (extractable with $1.0 \mathrm{M}$ sodium acetate at $\mathrm{pH} 5$ ); iron and manganese oxides fraction (extractable with hydroxylamine); organic matter fraction( extractable with $\mathrm{H}_{2} \mathrm{O}_{2}$ in $1 \mathrm{M} \mathrm{HNO}_{3}$ ); and residual fraction (difference between the total amount of metals in soil and the sum of the metals in the four fractions. All metals concentrations in the obtained extracts were determined using atomic absorption spectroscopy (contrAA 300).

The fractionation technique supposed that metals linked with the residual fraction (RS) are more fixed, less labile and less available for plant uptake than metals linked with the non-residual fractions (NORS, the sum of all fractions except the residual fraction.

\section{RESULTS AND DISCUSSIONS}

\section{Changes of metal fractions during incubation time}

The redistribution of $\mathrm{Cu}, \mathrm{Pb}$, and $\mathrm{Ni}$ among different fractions of control studied soils amended with $0.3 \%$ biosolid after 12 days ( 1 st cycle) and 60 days (5th cycle) was studied and the results are shown in Table 2.

Copper: After the 1st cycle the high percentage of $\mathrm{Cu}$ was observed in residual $(47.82 \%)$ or organic $(32.67 \%)$ fractions of calcareous or sandy soils, respectively. The high percentage of $\mathrm{Cu}$ in sandy soilorganic fraction could be explained by formation a very stable complexes with organic matter (Sancar et al., 2000; Zhou and Wong, 2001). In contrast, the least presence of $\mathrm{Cu}$ was found in exchangeable or carbonate fractions of calcareous or sandy soils, respectively. The low combination between $\mathrm{Cu}$ and carbonate fraction may be attributed to low calcium carbonate content in sandy soil (Table 1). Considerable changes in $\mathrm{Cu}$ fractions were noticed at the end of the incubation 
period (60 days). As seen in Table 2, for both soils there was a marked decrease in $\mathrm{Cu}$-residual fraction and this decrease was compensated with increasing of both $\mathrm{Cu}-$ oxide and organic fractions. Furthermore, the carbonate fraction of both soils was not significantly changed during 60 days incubation period since $\mathrm{Cu}$ can precipitate as $\mathrm{CuCO}_{3}$ in the presence of calcium carbonate (Ponizovsky et al.,2007). The $\mathrm{Cu}$ exchangeable bound fraction of sandy soil was increased over the 60 days incubation period; whereas this fraction in calcareous soil was not significantly changed.

The ability of heavy metals to be mobile in soil matrix could be mathematically expressed as the mobility index (MI) (Banat et al. 2003; Liu et al. 2007) which can be calculated according to the following model:

\section{$\mathrm{MI}=\Sigma(\mathrm{Fi} / \mathrm{Ti}) / \mathrm{n}$}

Where $\mathrm{Fi}$ is the metal concentration in exchangeable fraction concentration of the metal, $\mathrm{Ti}$ is the total concentration of the metal, and $\mathrm{n}$ is the number of the soil samples. The high lability and bioavailability of heavy metals in soils could be expected with high value of MI (Ahumada et al. 1999; Narwal et al. 1999).

The mobility index of $\mathrm{Cu}$ was used to show the effect of incubation time on $\mathrm{Cu}$ mobility through both soils. The higher MI (\%) of $\mathrm{Cu}$ in sandy soil ( 9.7) than calcareous soil (5.7) through 1st incubation period in addition to increasing $\mathrm{Cu}-\mathrm{MI}$ in sandy soils up to 11.1 as a result of prolonging incubation time (60 days) indicates more availability and mobility of $\mathrm{Cu}$ in sandy soil than calcareous soil.

Lead: During the first 12 days incubation, $\mathrm{Pb}$ in calcareous soil was mainly associated with residual phase $(44.5 \%)$ followed by carbonate phase $(22.7 \%)$ while exchangeable phase displayed the least existence (3.2\%). The high presence of $\mathrm{Pb}$ in carbonate fraction was compatible with the FTIR spectroscopy examination of Qian et al., 2017 who found $\mathrm{Pb}$ precipitate as hydrocerussite (lead hydroxycarbonate, $\mathrm{Pb}_{3}\left(\mathrm{CO}_{3}\right)_{2}(\mathrm{OH})_{2}$ or $\left.2 \mathrm{PbCO}_{3} \cdot \mathrm{Pb}(\mathrm{OH})_{2}\right)$. In sandy soils, $\mathrm{Pb}$ distribution among different phases was in the following order: oxide $(35.1 \%)>$ residual $(34 \%)>$ carbonate $(14.5 \%)>$ organic $(11.6 \%)>$ exchangeable $(4.8 \%)$. The high ability of $\mathrm{Pb}$ to form both innersphere metal surface complexes and/or precipitate phases as metal hydroxide could be the reason for the high $\mathrm{Pb}$ percentage in oxide phase (Brown et al., 2001and Sparks, 2001). The effect of 60 days aging on redistribution of $\mathrm{Pb}$ fractions was pronounced for both soils. As seen in Table 2, the exchangeable fractions of calcareous and sandy soils were significantly increased from $3.2 \%$ and $4.8 \%$ to $5.7 \%$ and $9.2 \%$, respectively. In contrast, residual fractions of both soils were dramatically decreased. Thus, $\mathrm{Pb}$ becomes increasingly available due to redistribution of $\mathrm{Pb}$ in exchangeable and residual fractions over 60 days incubation. However, the increase of $\mathrm{Pb}$ in oxide and organic fractions for both soils and carbonate fraction in calcareous soil over this period (Table2) could recompense this $\mathrm{Pb}$-available increase. Oxide fraction can be considered sinks for heavy metals in alkaline conditions (McBride, 1994); since several metals such as $\mathrm{Pb}$ can be adsorbed or diffused into the oxide structure, decreasing its mobility (Contin et al., 2008; Schwertmann and Taylor, 1989). Also, organic fraction can reduce $\mathrm{Pb}$ availability in highly $\mathrm{pH}$ value through formation of strong inner-sphere complexes between $\mathrm{Pb}$ and soil organic matter (Basta et al.,2005). Furthermore, metals mobility in carbonate calcium-rich soils could be significantly reduced (Elkhatib et al.,1991). The Pb mobility index in both soils increased as incubation time prolonged from 30 days to 60 days reflecting potential more $\mathrm{Pb}$ availability over incubation period.

Nickel: This metal showed the lowest changedamong the studied metals- in metal redistribution over the incubation period. However, a lowering of the residual fraction for both soils and a conforming increase of $\mathrm{Ni}$ bound to oxides fraction was found (Table 2). The mobility index of $\mathrm{Ni}$ was also not significantly differed in both soils due to incubation time progress. The low $\mathrm{Ni}$-fractions redistribution during incubation time is in line with Sánchez-Martín et al. (2007) study that discusses heavy metals fractionation -including $\mathrm{Ni}$ - of sewage sludge amended soils over 18 months incubation time.

With respect to all studied metals, in general, the decrease of residual fraction over 60 days incubation time was observed in both soils and simultaneously other fractions were occupied with these residual fraction- released metals. The redistribution of metals between residual and other fractions could be attributed to dissolution of sludge-inorganic and organic compounds existent in residual fraction causing meals concentration in other fractions to increase (Smith, 1996).

\section{Effect of nWTR on metal fractions}

The effect of $2 \%$ bulk WTR and $0.1 \%$ and $0.3 \%$ nWTR treated calcareous and sandy soils that amended with biosolid ( $3 \%, \mathrm{w} / \mathrm{w})$ on $\mathrm{Cu}, \mathrm{pb}$, and $\mathrm{Ni}$ fractionation was examined and the results are stated in Figure 1.

Application of both bulk WTR and nWTR treated both soils substantially reduced the NORS $\mathrm{Cu} / \mathrm{Ni}$ fractions and simultaneously increased RS both metals fractions. At rate of $2 \%$ WTR, for instance, NORS-Cu and $\mathrm{Ni}$ fractions in sandy soil were decreased from $78.6 \%$ and $55.89 \%$ to $62.8 \%$ and $46 \%$ whereas $\mathrm{RS}-\mathrm{Cu}$ 
and $\mathrm{Ni}$ fractions were increased from $21.4 \%$ and $44.1 \%$ to $37.19 \%$ and $53 \%$, respectively. Furthermore, addition of $2 \%$ WTR to both soils significantly increased both $\mathrm{Pb}$-oxides and $\mathrm{RS}$ fractions since oxides and $\mathrm{RS}$ fractions of calcareous soil -as example- were increased from $15.9 \%$ and $44.5 \%$ to $19.5 \%$ and $47.6 \%$, respectively. The increase of $\mathrm{Pb}$ associated with oxide fractions could also -in addition to RS fractioncontribute in $\mathrm{Pb}$ immobilization in soils since metal bound to oxide supposes to be less mobility and plant uptake availability (Phillips and Chapple 1995). These findings indicate the function of WTR in converting studied metals from the more labile form to more stable and less mobile form that coincide with preceding studies (Moharem, 2012; Moharem et al., 2013; Elkhatib and Moharem, 2015; Elkhatib et al., 2015). When nWTR at $0.3 \%$ rate was utilized, more existence of $\mathrm{Cu}, \mathrm{Pb}$ and $\mathrm{Ni}$ were found in $\mathrm{RS}$ fraction up to $85.77 \%, 59.36 \%$, and $88.18 \%$, respectively with also less existence in NORS of $\mathrm{Cu}(14.23 \%)$ and $\mathrm{Ni}$ $(11.82 \%)$ fractions regarding calcareous soil -as example. Furthermore, more $\mathrm{Pb}$-oxide fraction of both soils was increased reaching $47.39 \%$ for sandy soil. These findings indicate the more nWTR effectiveness in reducing studied metals mobility in biosolid amended both soils which can be attributed to the large specific surface area and multiple active sites of nWTR than bulk one (Elkhatib et al., 2015b; Ponizovskii and Mironenko, 2001). These results are consistence with previous study concerning the potential of nWTR to immobilize heavy metals in contaminated soils (Moharem, et al., 2019; Elkhatib et al., 2018, 2017).

\section{Effect of incubation time on metal fractions of nWTR-treated soils}

The redistribution of $\mathrm{Cu}, \mathrm{Pb}$, and $\mathrm{Ni}$ forms after the $5^{\text {th }}$ cycle (60 days) in studied soils as a result of adding $0.1 \%$ and $0.3 \%$ nWTRs was studied comparing with 1 st cycle (12 days) and the results are illustrated in Table 2.

The tendency for the forms diversion of the $\mathrm{Cu}$ in the two soils remained relatively unchanged as the time increase of incubation. However, there was a small alteration in all content forms by the 60th day with slightly increase of residual $\mathrm{Cu}$ versus decrease of exchangeable and carbonate $\mathrm{Cu}$. The observed relatively no change in $\mathrm{Cu}$ forms between the two periods meant that aging would not affect the speciation proportion of $\mathrm{Cu}$. However, the slightly increase of $\mathrm{Cu}$ proportion in RS fraction as a result of incubation time increased would keep $\mathrm{Cu}$ in a stable form in this fraction with little fluctuation within incubation period.

The redistribution of $\mathrm{Pb}$ forms after 60 days was noticed for the two soils. The content of the exchangeable and carbonate $\mathrm{Pb}$ showed a small change, while the organic matter $\mathrm{Pb}$ was decreased at the end of incubation period. The remarkable reduction in organic fraction $\mathrm{Pb}$ may be due to decomposition of organic matter binding $\mathrm{Pb}$ within 60 days of incubation period. The residual $\mathrm{Pb}$ continued to increase, up to $63.4 \%$ and $47.41 \%$ for calcareous and sandy soils, respectively. Apparently, the increasing of residual fraction was mainly from the decreasing of organic fraction.

The effect of incubation period on $\mathrm{Ni}$ fractionation was considerable especially for sandy soils. As seen in Table 2, Ni residual fraction was increased significantly as incubation time finished, and this increase was arisen from the decrease of all fractions of NORS. For instance, Ni- residual fraction was increased to reach $92.64 \%$ and $91.27 \%$ whereas NORS were decreased till $7.36 \%$ and $8.73 \%$ for calcareous and sandy soils, respectively. The observed fluctuation of $\mathrm{Ni} \mathrm{RS}$ and NORS fractions could be elucidated by the metals exchangeable between the RS and NORS fractions during the entire period of incubation. many factors could control metal conversion and allocation in soil system, and in this study, decrease of organic fraction$\mathrm{Ni}$ as the increase of incubation time may be attributed to decomposition of metal Bound to organic matter in the amended soils, causing an increase in further fractions such as residual fraction. Finally, the redistribution of $\mathrm{Pb}$ and $\mathrm{Ni}$ after 60 days was towards more chemically stable and less bioavailability.

\section{Metals desorption vs time}

The effect of time during the $5^{\text {th }}$ cycle (60 days incubation) on $\mathrm{Cu}, \mathrm{Pb}$, and $\mathrm{Ni}$ desorption using DTPA extractant from calcareous and sandy soils nonamended (control) and amended with both bulk and nano-sized WTR are shown in Fig. 2. For control soils, the desorbed amount of the three metals from both soils was decreased as a results of the incubation time increased. An almost linear curve of $\mathrm{Cu}$ and $\mathrm{Pb}$ release with time was noticed in both soils. On contrast, $\mathrm{Ni}$ release versus time was biphasic which characterized by a fast desorption reaction followed by a much slower rate. The higher amounts of all metals released were found for sandy soil rather than calcareous soil which could refer to higher calcium carbonate and $\mathrm{OM}$ content of the calcareous soil than of sandy soil. Carbonate fraction can substantially immobilize heavy metals by providing an surface adsorbing or buffering $\mathrm{pH}$ at values where metals hydrolyzes and precipitation can occur (Moral et al., 2005). Moreover, soil organic matter can 
Table 2. Percentage of $\mathrm{Cu}, \mathrm{Pb}$, and Ni forms after first and fifth incubation cycles in the two studied soils amended with $0,0.1$ and $0.3 \%$ nWTRs

\begin{tabular}{|c|c|c|c|c|c|c|c|c|c|c|c|}
\hline \multirow{2}{*}{$\begin{array}{l}\text { nWTRs } \\
\text { Rate \% } \\
\end{array}$} & \multirow{3}{*}{$\begin{array}{c}\text { Incubation } \\
\text { cycle }\end{array}$} & \multicolumn{10}{|c|}{ Metal forms (\%) } \\
\hline & & \multicolumn{5}{|c|}{ Calcareous } & \multicolumn{5}{|c|}{ Sandy } \\
\hline & & Exch & carb & Ox & OM & $\operatorname{Res}$ & Exch & carb & $\mathbf{O x}$ & $\mathbf{O M}$ & Res \\
\hline & & & & & & $\mathrm{C}$ & & & & & \\
\hline \multirow{2}{*}{0} & First & $5.67 \pm 0.45^{\mathrm{a}}$ & $17.39 \pm 0.88^{\mathrm{a}}$ & $13.17 \pm 0.71^{\mathrm{b}}$ & $15.95 \pm 0.83^{b}$ & $47.82 \pm 0.81^{\mathrm{a}}$ & $9.67 \pm 0.83^{b}$ & $6.47 \pm 0.51^{\mathrm{a}}$ & $29.82 \pm 0.76^{b}$ & $32.67 \pm 0.76^{b}$ & $21.36 \pm 0.83^{\mathrm{a}}$ \\
\hline & Fifth & $5.312 \pm 0.23^{\mathrm{a}}$ & $16.932 \pm 0.43^{\mathrm{a}}$ & $17.784 \pm^{\mathrm{b}}$ & $18.531 \pm 0.67^{\mathrm{a}}$ & $41.441 \pm 0.4^{\mathrm{b}}$ & $11.134 \pm 0.7^{\mathrm{a}}$ & $7.134 \pm 0.41^{\mathrm{a}}$ & $33.654 \pm 0.91^{\mathrm{a}}$ & $35.976 \pm 0.4^{\mathrm{a}}$ & $12.102 \pm 0.5^{b}$ \\
\hline \multirow{2}{*}{0.1} & First & $2.60 \pm 0.4^{\mathrm{a}}$ & $8.43 \pm 0.72^{\mathrm{a}}$ & $7.83 \pm 0.95^{\mathrm{a}}$ & $9.43 \pm 0.55^{\mathrm{a}}$ & $71.71 \pm 0.7^{\mathrm{b}}$ & $5.37 \pm 0.7^{\mathrm{a}}$ & $3.19 \pm 0.48^{\mathrm{a}}$ & $15.34 \pm 0.9^{\mathrm{a}}$ & $19.79 \pm 0.8^{\mathrm{a}}$ & $56.31 \pm 0.7^{\mathrm{b}}$ \\
\hline & Fifth & $1.93 \pm 0.71^{\mathrm{a}}$ & $6.92 \pm 0.48^{b}$ & $6.89 \pm 0.63^{a}$ & $9.02 \pm 0.85^{\mathrm{a}}$ & $75.24 \pm 0.5^{\mathrm{a}}$ & $4.43 \pm 0.49^{a}$ & $2.36 \pm 0.67^{\mathrm{a}}$ & $14.99 \pm 0.7^{\mathrm{a}}$ & $19.29 \pm 0.8^{a}$ & $58.93 \pm 0.69^{a}$ \\
\hline \multirow{3}{*}{0.3} & First & $1.086 \pm 1.13^{\mathrm{a}}$ & $2.77 \pm 0.76^{\mathrm{a}}$ & $5.84 \pm 0.83^{\mathrm{a}}$ & $4.53 \pm 0.51^{\mathrm{a}}$ & $85.77 \pm 0.7^{\mathrm{a}}$ & $2.47 \pm 0.5^{\mathrm{a}}$ & $1.81 \pm 0.71^{\mathrm{a}}$ & $8.44 \pm 0.83^{\mathrm{a}}$ & $9.02 \pm 0.51^{\mathrm{a}}$ & $78.27 \pm 0.7^{\mathrm{b}}$ \\
\hline & Fifth & $0.67 \pm 0.83^{\mathrm{a}}$ & $1.34 \pm 0.71^{\mathrm{b}}$ & $5.06 \pm 0.83^{\mathrm{a}}$ & $4.13 \pm 0.51^{\mathrm{a}}$ & $88.8 \pm 0.88^{\mathrm{a}}$ & $1.89 \pm 0.51^{\mathrm{a}}$ & $0.68 \pm 0.76^{\mathrm{b}}$ & $8.14 \pm 0.83^{\mathrm{a}}$ & $8.67 \pm 0.71^{\mathrm{a}}$ & $80.62 \pm 0.83^{\mathrm{a}}$ \\
\hline & & \multicolumn{10}{|c|}{$\mathrm{Pb}$} \\
\hline \multirow{2}{*}{0} & First & $3.20 \pm 0.76^{\mathrm{b}}$ & $22.7 \pm 0.85^{b}$ & $15.90 \pm 0.79^{b}$ & $13.7 \pm 0.76^{\mathrm{b}}$ & $44.5 \pm 0.85^{\mathrm{a}}$ & $4.80 \pm 0.76^{b}$ & $14.5 \pm 0.83^{\mathrm{a}}$ & $35.1 \pm 0.51^{\mathrm{b}}$ & $11.6 \pm 0.76^{\mathrm{b}}$ & $34.00 \pm 0.85^{\mathrm{a}}$ \\
\hline & Fifth & $5.7 \pm 0.21^{\mathrm{a}}$ & $24.87 \pm 0.88^{\mathrm{a}}$ & $18.98 \pm 0.41^{\mathrm{a}}$ & $15.17 \pm 0.80^{\mathrm{a}}$ & $35.28 \pm 0.14^{\mathrm{b}}$ & $9.2 \pm 0.61^{\mathrm{a}}$ & $15.94 \pm 0.21^{\mathrm{a}}$ & $38.65 \pm 0.61^{\mathrm{a}}$ & $13.03 \pm 0.76 a$ & $23.18 \pm 0.71^{b}$ \\
\hline \multirow{2}{*}{0.1} & First & $1.2 \pm 0.71^{\mathrm{a}}$ & $9.34 \pm 0.91^{\mathrm{a}}$ & $22.34 \pm 0.82^{\mathrm{a}}$ & $8.17 \pm 0.78^{a}$ & $58.95 \pm 0.74^{\mathrm{b}}$ & $1.8 \pm 0.75^{\mathrm{a}}$ & $5.04 \pm 0.88^{\mathrm{a}}$ & $41.85 \pm 0.71^{\mathrm{a}}$ & $5.91 \pm 0.79^{a}$ & $45.4 \pm 0.79^{b}$ \\
\hline & Fifth & $0.98 \pm 0.69^{a}$ & $9.01 \pm .081^{\mathrm{a}}$ & $20.42 \pm 0.81^{\mathrm{b}}$ & $6.56 \pm 0.59^{b}$ & $63.03 \pm 0.49^{\mathrm{a}}$ & $1.59 \pm 0.62^{\mathrm{a}}$ & $4.87 \pm 0.69^{a}$ & $40.45 \pm 0.82^{\mathrm{a}}$ & $3.76 \pm 0.95^{b}$ & $49.33 \pm 0.66^{\mathrm{a}}$ \\
\hline \multirow{3}{*}{0.3} & First & $0.5 \pm 0.76^{\mathrm{a}}$ & $5.31 \pm 0.78^{a}$ & $27.51 \pm 0.85^{\mathrm{a}}$ & $7.32 \pm 0.79^{a}$ & $59.36 \pm 0.74^{b}$ & $0.3 \pm 0.76^{\mathrm{a}}$ & $4.17 \pm 0.85^{\mathrm{a}}$ & $47.39 \pm 0.79^{a}$ & $3.64 \pm 0.76^{\mathrm{a}}$ & $44.5 \pm 0.85^{\mathrm{b}}$ \\
\hline & Fifth & $0.48 \pm 0.79^{\mathrm{a}}$ & $5.11 \pm 0.76^{\mathrm{a}}$ & $26.45 \pm 0.7^{a}$ & $4.56 \pm 0.85^{\mathrm{a}}$ & $63.4 \pm 1.13^{\mathrm{a}}$ & $0.23 \pm 0.76^{\mathrm{a}}$ & $4.04 \pm 0.85^{\mathrm{a}}$ & $46.76 \pm 0.76^{\mathrm{a}}$ & $1.56 \pm 0.83^{b}$ & $47.41 \pm 0.51^{\mathrm{a}}$ \\
\hline & & \multicolumn{10}{|c|}{$\mathrm{Ni}$} \\
\hline \multirow{2}{*}{0} & First & $2.96 \pm 0.96^{\mathrm{a}}$ & $22.34 \pm 1.04^{\mathrm{a}}$ & $18.82 \pm 1.14^{\mathrm{b}}$ & $6.72 \pm 0.83^{\mathrm{a}}$ & $49.07 \pm 1.14^{\mathrm{a}}$ & $4.39 \pm 1.14^{\mathrm{a}}$ & $16.43 \pm 0.83^{a}$ & $23.43 \pm 1.13^{b}$ & $11.64 \pm 1.15^{\mathrm{a}}$ & $44.11 \pm 1.12^{\mathrm{a}}$ \\
\hline & Fifth & $3.54 \pm 0.86^{\mathrm{a}}$ & $23.07 \pm 0.51^{\mathrm{a}}$ & $20.76 \pm 0.11^{\mathrm{a}}$ & $7.04 \pm 0.98^{\mathrm{a}}$ & $45.59 \pm 0.17^{b}$ & $5.23 \pm 0.83^{\mathrm{a}}$ & $16.87 \pm 0.81^{\mathrm{a}}$ & $25.98 \pm 0.99^{a}$ & $11.87 \pm 0.71^{\mathrm{a}}$ & $40.05 \pm 0.71^{\mathrm{b}}$ \\
\hline \multirow{2}{*}{0.1} & First & $0.41 \pm 0.81^{\mathrm{a}}$ & $12.12 \pm 0.66^{\mathrm{a}}$ & $9.74 \pm 0.67^{\mathrm{a}}$ & $2.01 \pm 0.74^{\mathrm{a}}$ & $75.72 \pm 0.71^{\mathrm{b}}$ & $2.01 \pm 0.71^{\mathrm{a}}$ & $8.12 \pm 0.97^{\mathrm{a}}$ & $14.63 \pm 0.88^{\mathrm{a}}$ & $6.86 \pm 0.71^{\mathrm{a}}$ & $68.38 \pm 0.77^{b}$ \\
\hline & Fifth & $0.28 \pm 0.87^{b}$ & $10.31 \pm 0.82^{b}$ & $7.34 \pm 0.87^{b}$ & $1.43 \pm 0.88^{a}$ & $80.64 \pm 0.97^{a}$ & $1.89 \pm 0.98^{a}$ & $7.01 \pm 0.59^{a}$ & $12.67 \pm 0.84^{b}$ & $5.64 \pm 0.96^{\mathrm{a}}$ & $72.79 \pm 0.72^{\mathrm{a}}$ \\
\hline \multirow{2}{*}{0.3} & First & $0.18 \pm 0.04^{\mathrm{a}}$ & $5.31 \pm 0.76^{\mathrm{a}}$ & $4.52 \pm 1.13^{\mathrm{a}}$ & $1.81 \pm 0.85^{\mathrm{a}}$ & $88.18 \pm 1.04^{b}$ & $0.92 \pm 1.14^{\mathrm{a}}$ & $3.15 \pm 0.83^{\mathrm{a}}$ & $5.73 \pm 1.14^{\mathrm{a}}$ & $3.87 \pm 1.15^{\mathrm{a}}$ & $86.33 \pm 1.13^{b}$ \\
\hline & Fifth & $0.01 \pm 0.04^{b}$ & $3.56 \pm 1.13^{b}$ & $3.12 \pm 1.14^{\mathrm{a}}$ & $0.67 \pm 0.83^{a}$ & $92.64 \pm 1.15^{\mathrm{a}}$ & $0.76 \pm 1.14^{\mathrm{a}}$ & $2.12 \pm 0.83^{b}$ & $3.64 \pm 1.13^{b}$ & $2.21 \pm 1.16^{\mathrm{b}}$ & $91.27 \pm 0.85^{\mathrm{a}}$ \\
\hline
\end{tabular}

All values are average of three replications. Means within a (vertical) column for both incubation time followed by the same letter do not differ significantly by the Duncan's

multiple range test $(\mathrm{p}<0.05)$. 


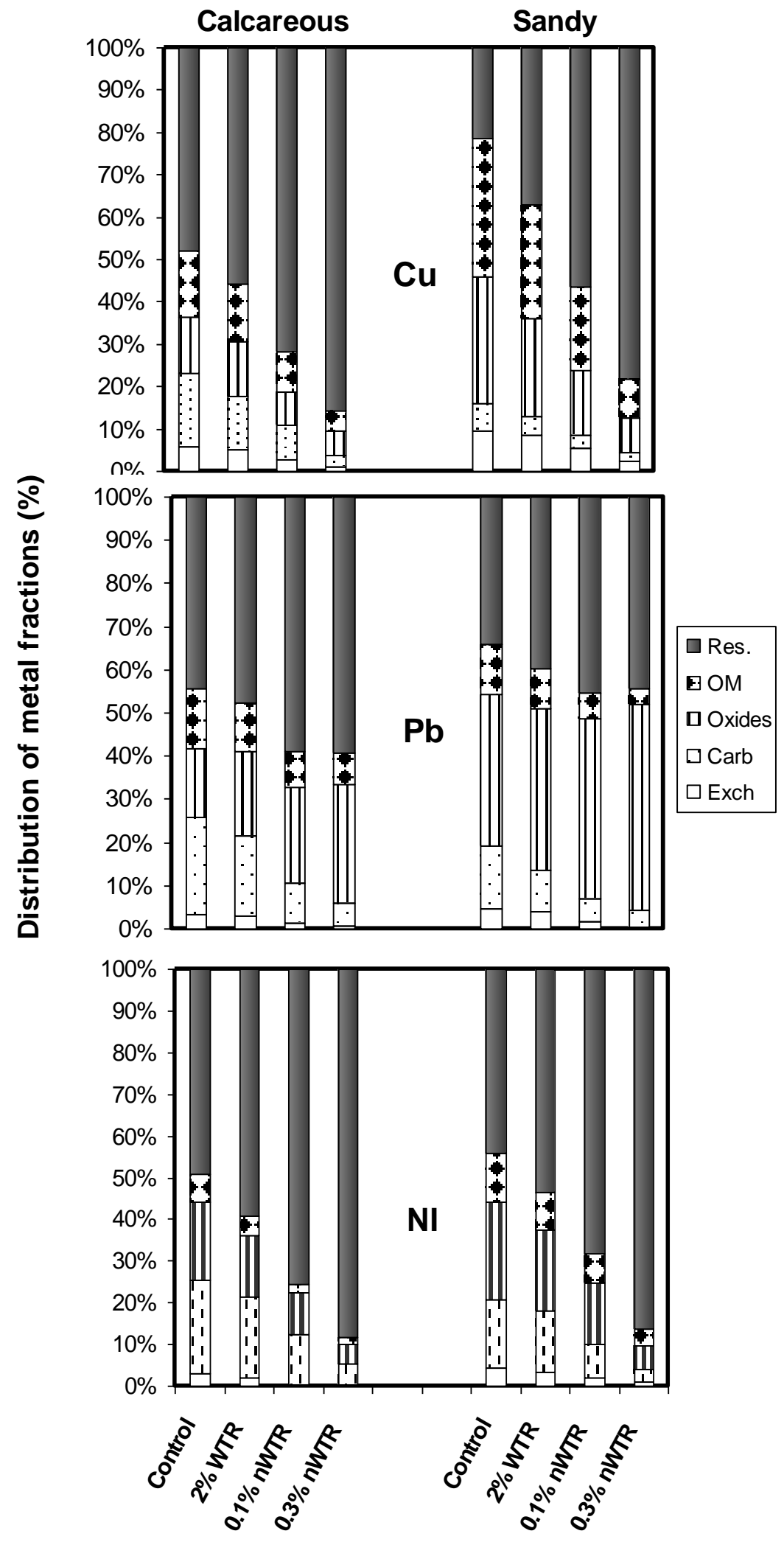

Fig .1. Relative percentage of $\mathrm{Cu}, \mathrm{Pb}$ and $\mathrm{Ni}$ fractions for the two studied soils treated with biosolids (3\%, w/w) and amended with .WTR/nWTR. WTR, water treatment residual; nWTR, water treatment residual nanoparticles 
strongly sorb heavy metals causing reducing their mobility in soil (Adriano, 2001). Among the three metals studied in both soils, Ni showed the least amount of desorbed metal followed by $\mathrm{Pb}$ while the higher amount of desorbed metal was for $\mathrm{Cu}$. The low amount of desorbed Ni from both soils relative to other both metals was coincide with the data obtained from metals mobility index which showed the lower mobility index of $\mathrm{Ni}$ comparing with the other metals (Data not shown). This finding indicates the higher affinity of alkaline soil to sorb $\mathrm{Ni}$ than $\mathrm{Cu}$ and $\mathrm{Pb}$ which may be attributed to the higher ionic potential of $\mathrm{Ni}$ (2.6) than for $\mathrm{Cu}$ (2.5) and $\mathrm{Pb}$ (1.9) (Kabata-Pendias and Pendias, 2001). Furthermore, Kabata-Pendias and Pendias (2001) demonstrated that the ability of metal for precipitation can be increased as the increase of metal ionic potential.

The amount of desorbed $\mathrm{Cu}, \mathrm{Pb}$, and $\mathrm{Ni}$ from both soils was significantly decreased after application of bulk WTR and nWTR (Fig 2 ). This reduction in metals desorption was more intense in nWTR treatment especially at high treatment rate. For instance, in $0.30 \%$ nWTR at the first 12 days the $\mathrm{Cu}, \mathrm{Pb}$, and Ni desorbed from calcareous soil decreased by 70.23, 74.04, and 70.14 , respectively- comparing with each own control. Clearly, nWTR application increased the sorbed metals onto the active surfaces of this nano-sized residuals leading to decreasing movement of metals towards solution. The high content of non-crystalline Fe/Al(hydr)oxides, and Si-oxide of nWTR that proved from previous study of Elkhatib et al. (2015a)- using EDX and X-ray diffraction analysis- could be responsible for the high ability of metals towards nWTR-surface reaction sites. The strong bonding between heavy metals -including $\mathrm{Pb}, \mathrm{Cu}$, and $\mathrm{Ni}$ - and metal-oxides was found using molecular-scale X-ray spectroscopic tool which elucidated chemo-sorption reaction between metal and oxide-surfaces followed by metal precipitation in hydroxide form (Brown and Parks 2001; Sparks, 2001). Furthermore, other studies showed that heavy metals demonstrated desorption hysteresis process on goethite (Grossl and Sparks, 1994; Barrow et al., 2012). This results reflect the capability of nWTR holding amorphous iron, aluminum (hydr)oxides to immobilize studied metals in contaminated soils.

\section{Desorption kinetic models}

The desorption data were modeled for further description of the effectiveness of WTR/nWTR treatment with time on the three metals desorption process from both soils. The applied kinetic models are Elovich (Elkhatib and Hern, 1988), parabolic diffusion (Laidler, 1965), power function (Elkhatib et al., 1992), first order, and second order equations. The best fit of these models for the experimental desorption data was setup according to the highest coefficient of determination $\left(\mathrm{R}^{2}\right)$ and the lowest standard error (SE) values. The high coefficient of determination and low SE values of parabolic diffusion and Elovich equations indicates that both models can successfully describe all desorption kinetic data. In contrary, power function, first order, and second order equations failed to express the all kinetic data which attributed to either high SE values of power function or low $\mathrm{R}^{2}$ and high $\mathrm{SE}$ values of first and second order equations (data not shown). Table 3 displays the values of kinetic parameters for the two fit models used to describe the desorption kinetic data.

\section{1-Intraparticle diffusion model}

The plot of the Weber and Morris intraparticle diffusion model (metal desorbed versus $\mathrm{t}^{0.5}$ ) for the desorption of $\mathrm{Cu}, \mathrm{Pb}$, and $\mathrm{Ni}$ from control and WTR/nWTR amended both soils gives a straight line but it does not pass through the origin; consequently intraparticle diffusion is not the sole rate-limiting step in the overall desorption process.. These plots are shown in Fig 3 for sandy soils-as example. The intraparticle diffusion rate constant $\left(k_{d}, \mu g g^{-1} \min ^{-1 / 2}\right)$ was determined from the slope of the linear curve. This $k_{d}$ value is considered a measure of the desorption rate of metals. The $\mathrm{k}_{\mathrm{d}}$ value was lower for nWTR-treated soils comparing with other treatments (control and bulk WTR) with more pronounced at high rate $(0.3 \%)$ as seen in Table 3. The low metal desorption rate from nWTR-treated soils could be due to specific adsorption on high energy sites of nWTR. Moreover, the intercept of the linear plot indicates an thought about boundary layer thickness which increase with the increase of the intercept (Weber and Morriss, 1963; Bayramoglu et al., 2009). The boundary layer thickness was significantly decrease as a results of nWTR treatment which indicate the contribution of the nWTR-surface sorption in the rate controlling step.

\section{2-Elovich model}

The plot of $\mathrm{q}$ (the amount of metal desorbed) against $\ln t$ gives a straight line with the slope of $(1 / \beta)$ and intercept of $(1 / \beta) \ln (\alpha \beta)$. where $\alpha$ is the initial desorption rate $\left(\mathrm{mg} \mathrm{g}^{-1} \mathrm{~min}^{-1}\right)$ and $\beta$ is related to the extent of surface coverage $\left(\mathrm{mg} \mathrm{g}^{-1}\right)$ and activation energy for chemisorptions. The Elovich parameters $(\beta$, $\alpha)$ are calculated from the slope and intercept of the linear plot. As seen in Table 3, the initial desorption rate values $(\ln \alpha)$ were low for all nWTR rates indicating increase of the rate of metal chemisorption (Elkhatib et al., 1992, 2001; Loukidou et al., 2004); consequently reduces the rate of metal release from nWTR-surfaces of treated soils into the solution. 
Table 3. Kinetic parameters of $\mathrm{Cu}, \mathrm{Pb}$, and Ni desorption from calcareous and sandy soils treated with .WTR/nWTR

\begin{tabular}{|c|c|c|c|c|c|c|c|c|}
\hline \multirow{3}{*}{ Treatment } & \multicolumn{4}{|c|}{ Calcareous } & \multicolumn{4}{|c|}{ Sandy } \\
\hline & \multicolumn{8}{|c|}{$\begin{array}{c}\text { Parabolic Diffusion model } \\
q=\mathbf{a}+\mathbf{k}_{\mathbf{d}} \mathbf{t}^{1 / 2}\end{array}$} \\
\hline & $\mathbf{k}_{\mathbf{d}}$ & $\mathbf{a}$ & $\mathbf{R}^{2}$ & SE & $\mathbf{k}_{\mathbf{d}}$ & $\mathbf{a}$ & $\mathbf{R}^{2}$ & SE \\
\hline & \multicolumn{8}{|c|}{$\mathrm{Cu}$} \\
\hline $0 \% \mathrm{WTR}$ & 1.45 & 36.44 & 0.99 & 0.0128 & 1.00 & 50.74 & 0.99 & 0.05489 \\
\hline $2 \% \mathrm{WTR}$ & 0.97 & 24.29 & 0.99 & 0.0124 & 0.67 & 33.83 & 0.99 & 0.00987 \\
\hline $0.1 \%$ nWTR & 0.94 & 16.18 & 0.98 & 0.0223 & 0.45 & 27.19 & 0.97 & 0.00976 \\
\hline \multirow[t]{2}{*}{$0 \cdot 3 \%$ nWTR } & 0.24 & 10.18 & 0.99 & 0.0431 & 0.28 & 15.95 & 0.99 & 0.013421 \\
\hline & \multicolumn{8}{|c|}{$\mathrm{Pb}$} \\
\hline $0 \%$ WTR & 3.09 & 33.62 & 0.99 & 0.00789 & 4.28 & 52.72 & 0.97 & 0.003561 \\
\hline $2 \% \mathrm{WTR}$ & 1.93 & 21.01 & 0.99 & 0.0121058 & 2.85 & 33.74 & 0.95 & 0.02467 \\
\hline $0.1 \% \mathrm{nWTR}$ & 1.71 & 16.07 & 0.99 & 0.1031 & 1.69 & 20.41 & 0.97 & 0.03410 \\
\hline \multirow[t]{2}{*}{$0.3 \% \mathrm{nWTR}$} & 0.85 & 8.76 & 0.98 & 0.00913 & 1.31 & 14.37 & 0.97 & 0.00341 \\
\hline & \multicolumn{8}{|c|}{$\mathrm{Ni}$} \\
\hline $0 \%$ WTR & 1.74 & 16.31 & 0.98 & 0.1139 & 2.55 & 27.17 & 0.98 & 0.0210584 \\
\hline $2 \% \mathrm{WTR}$ & 1.09 & 10.19 & 0.98 & 0.001159 & 1.60 & 16.98 & 0.98 & 0.0075 \\
\hline $0.1 \% \mathrm{nWTR}$ & 0.71 & 6.62 & 0.97 & 0.0560 & 1.05 & 10.99 & 0.96 & 0.1098 \\
\hline \multirow[t]{4}{*}{$0.3 \%$ nWTR } & 0.53 & 4.91 & 0.97 & 0.00921 & 0.82 & 7.93 & 0.99 & 0.00973 \\
\hline & \multicolumn{8}{|c|}{$\begin{array}{c}\text { Elovich model } \\
q_{t}=(1 / \beta) \ln (\alpha \beta)+(1 / \beta) \ln t\end{array}$} \\
\hline & Lna & $\beta$ & $\mathbf{R}^{2}$ & SE & Lna & $\beta$ & $\mathbf{R}^{2}$ & SE \\
\hline & \multicolumn{8}{|c|}{$\mathrm{Cu}$} \\
\hline $0 \%$ WTR & 42.43 & 0.26 & 0.97 & 0.0154274 & 54.89 & 0.38 & 0.96 & 0.1006 \\
\hline $2 \% \mathrm{WTR}$ & 28.32 & 0.39 & 0.97 & 0.00322 & 36.51 & 0.57 & 0.96 & 0.01997 \\
\hline $0 \cdot 1 \%$ nWTR & 20.13 & 0.40 & 0.97 & 0.01459 & 28.73 & 0.86 & 0.92 & 0.002387 \\
\hline \multirow[t]{2}{*}{$0.3 \%$ nWTR } & 10.56 & 1.53 & 0.98 & 0.002667 & 16.61 & 1.33 & 0.99 & 0.0876 \\
\hline & \multicolumn{8}{|c|}{$\mathrm{Pb}$} \\
\hline $0 \%$ WTR & 45.53 & 0.12 & 0.96 & 0.001936 & 68.38 & 0.09 & 0.93 & 0.003227 \\
\hline $2 \% \mathrm{WTR}$ & 28.77 & 0.19 & 0.96 & 0.045748 & 43.17 & 0.14 & 0.93 & 0.04398 \\
\hline $0.1 \%$ nWTR & 23.06 & 0.22 & 0.97 & 0.004022 & 26.99 & 0.23 & 0.88 & 0.000681 \\
\hline \multirow[t]{2}{*}{$0.3 \% \mathrm{nWTR}$} & 12.26 & 0.45 & 0.95 & 0.0316 & 19.67 & 0.29 & 0.93 & 0.004347 \\
\hline & \multicolumn{8}{|c|}{$\mathrm{Ni}$} \\
\hline $0 \% \mathrm{WTR}$ & 23.69 & 0.22 & 0.98 & 0.001751 & 37.59 & 0.15 & 0.98 & 0.0038327 \\
\hline $2 \%$ WTR & 14.91 & 0.34 & 0.98 & 0.002387 & 23.74 & 0.24 & 0.98 & 0.00461 \\
\hline $0.1 \%$ nWTR & 9.97 & 0.49 & 0.94 & 0.001159 & 15.64 & 0.35 & 0.97 & 0.001332 \\
\hline $0.3 \% \mathrm{nWTR}$ & 7.18 & 0.67 & 0.94 & 0.021058 & 14.23 & 0.35 & 0.98 & 0.002833 \\
\hline
\end{tabular}

$\mathrm{R}^{2}$, determination coefficient; SE, standard error of estimate; WTR, water treatment residual; nWTR, water treatment residual nanoparticles; $\mathrm{q}$, metal desorbed $(\mathrm{mg} \mathrm{kg}-1)$; $\alpha$, the initial

desorption rate $\left(\mathrm{mg} \mathrm{g}-1 \mathrm{~min}^{-1}\right), \beta$, a constant related to the extent of surface coverage $(\mathrm{mg} \mathrm{g}-1)$; $\mathrm{k}_{\mathrm{d}}$, the intraparticle diffusion rate constant $\left(\mu \mathrm{g} \mathrm{g}^{-1} \mathrm{~min}^{-1 / 2}\right)$; a, a constan 
궁

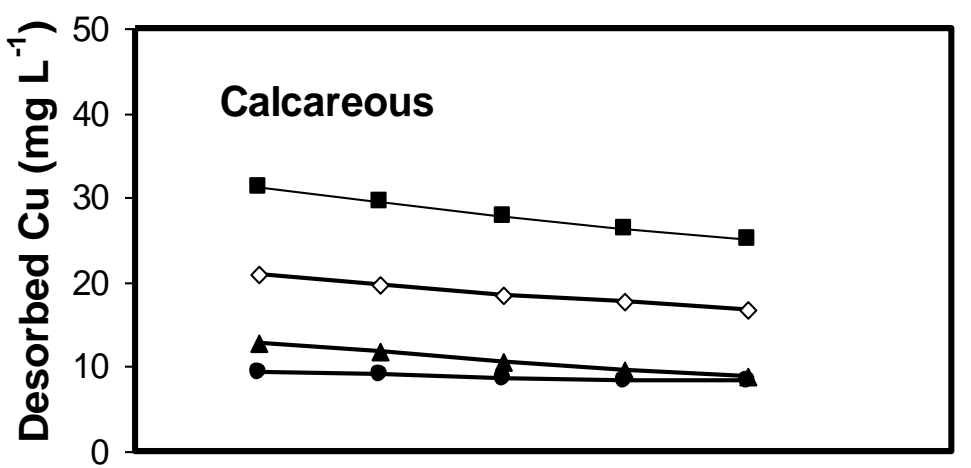

돌
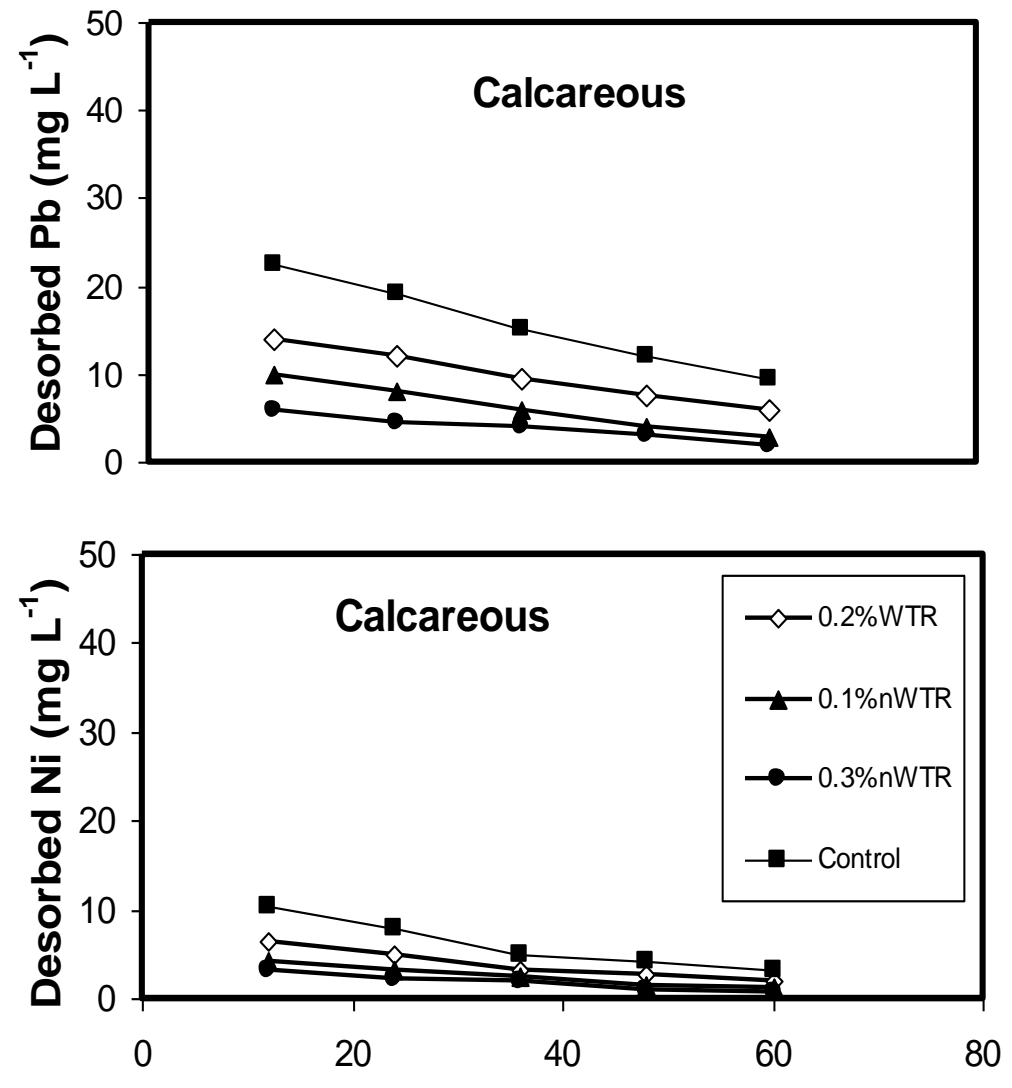
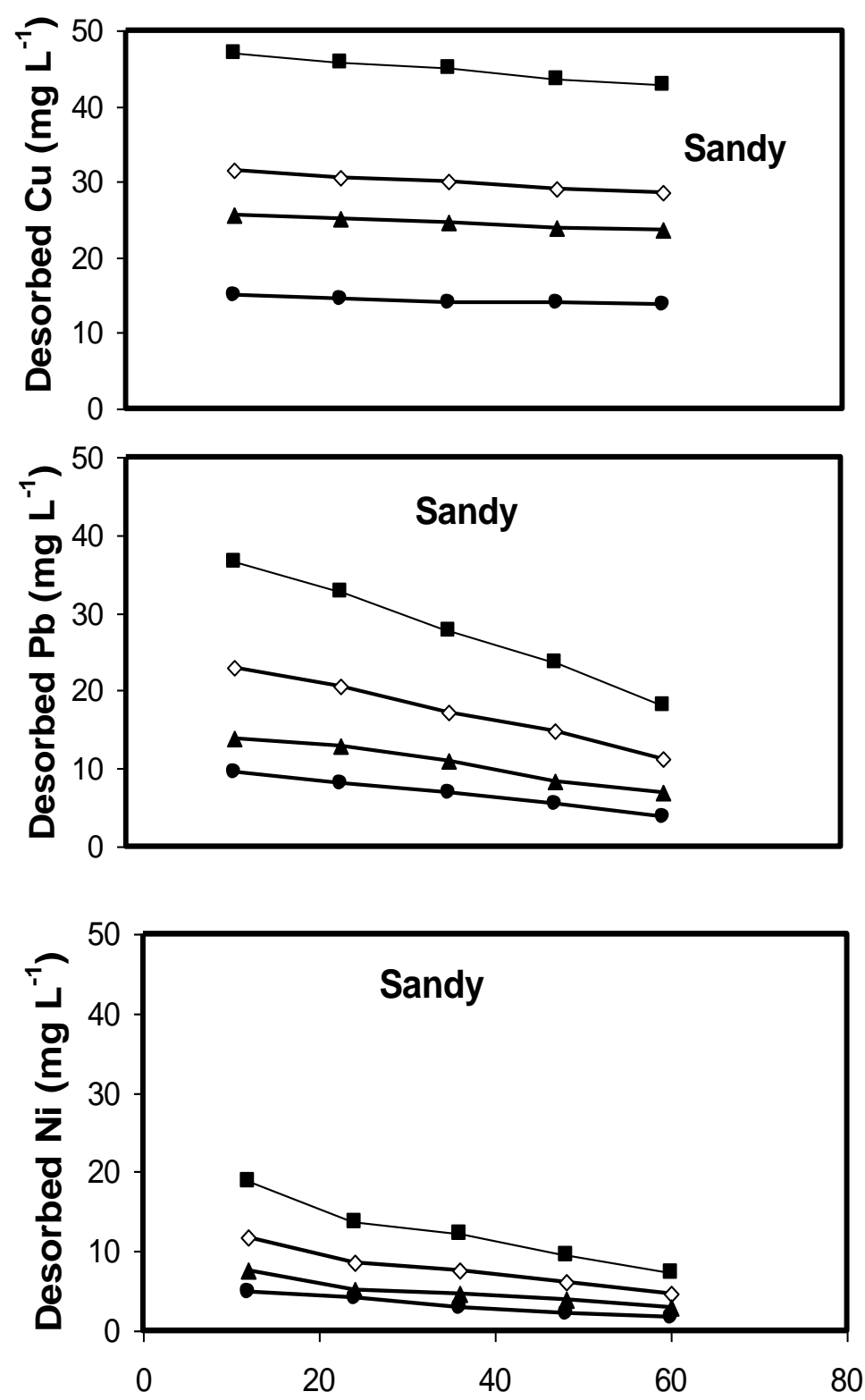

Time (days)

Fig. 2. Metals desorption during 60 days incubation period from the two studied soils treated with biosolids (3\%,w/w) and amended with .WTR/nWTR. WTR, water treatment residual; nWTR, water treatment residual nanoparticles 

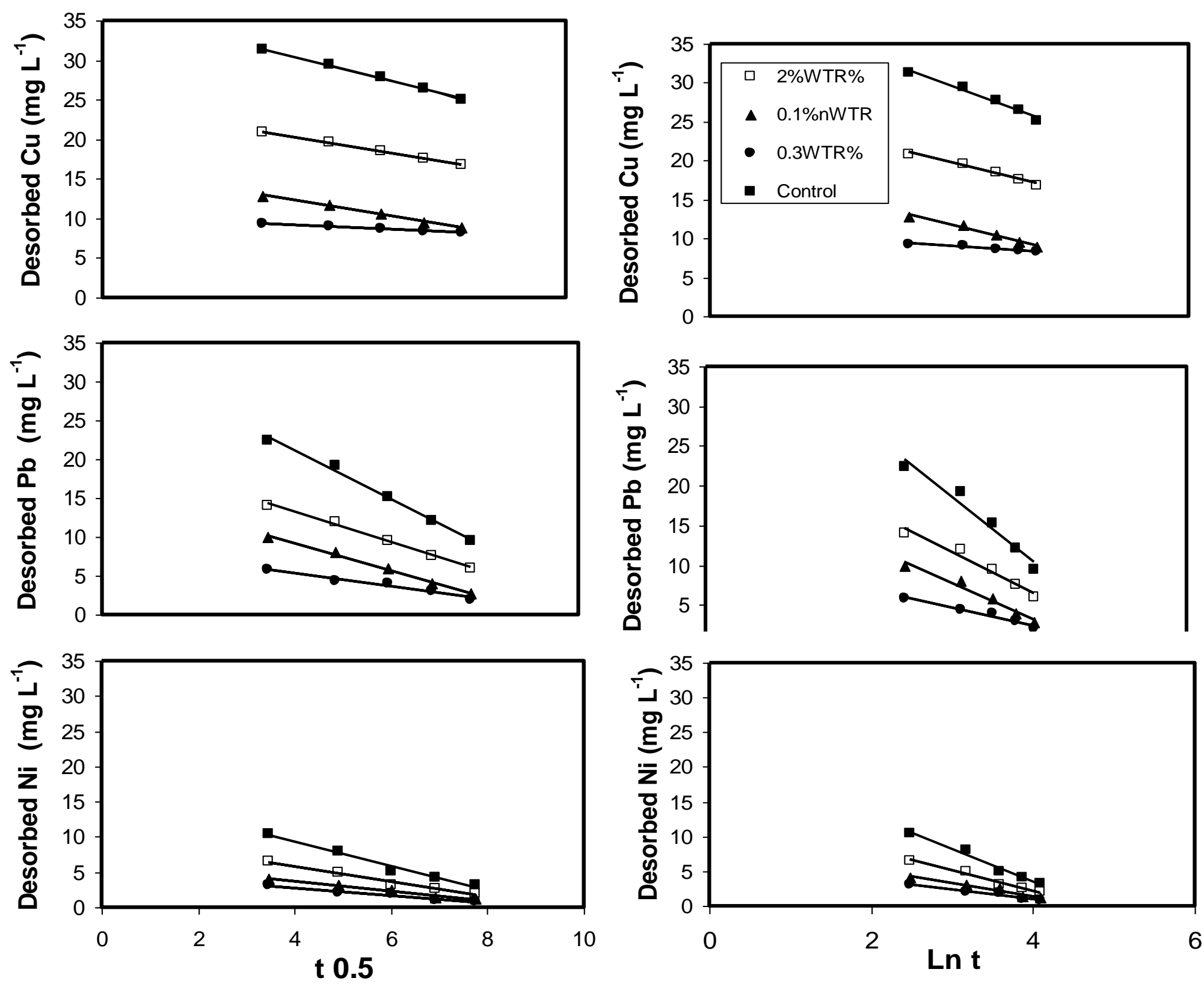

Fig. 3. Intraparticle diffusion (left graphs) and Elovich kinetic plots (right graphs) for metals desorption from calcareous soil treated with biosolids $(3 \%$, w/w) and amended with .WTR/nWTR. WTR, water treatment residual; nWTR, water treatment residual nanoparticles 


\section{CONCLUSION}

The effect of 60 days incubation period of biosolidtreated control soils on metals mobility and availability was examined as discussed from metals-fractions redistribution and mobility index findings. Thus, the redistribution of metals over the 60 days incubation period was towards more mobility and availability with more pronounced for $\mathrm{Cu}$ in sandy soil and less evident for $\mathrm{Ni}$. However, the increase of $\mathrm{Cu}$ and $\mathrm{Pb}$ in oxide and organic fractions for both soils over this period could recompense this $\mathrm{Pb} / \mathrm{Cu}$-available increase.

The nWTR amendments in both biosolid treated soils were efficient to increase both three metals- RS fraction and $\mathrm{Pb}$-oxide fraction with further increase of $\mathrm{Pb} / \mathrm{Ni}-\mathrm{RS}$ fraction over the 60 days incubation period. Although a little effect of aging in case of $\mathrm{Cu}$ was found, the slightly increase of $\mathrm{Cu}$ proportion in $\mathrm{RS}$ fraction as a result of incubation time increased would keep $\mathrm{Cu}$ in a stable form in this fraction with little fluctuation within incubation period. Furthermore, the DTPA-desorbed metals within the five wetting drying cycles were significantly decreased as a results of nWTR addition. Obviously, these results indicate the potential of using nWTR as a land amendment to mitigate heavy metals hazardous impacts in biosolids treated soils; so, it is recommended to added nWTR with biosolids once land application of biosolid.

\section{REFERENCES}

Adriano, D. C. 2001. Trace Elements in Terrestrial Environments. 2nd ed. Springer-Verlag, New York and CRC Press, Baton Rouge.

Ahumada, I., J. Mendoza, L. Ascar. 1999. Sequential extraction in soils irrigated with waste water. Commun Soil Sci. Plan. 30:1057-1519.

Banat, K.M., F.M. Howari, A.A. Al-Hamad. 2003. Heavy metals in urban soils of central Jordan: should we worry about their environmental risks? Adv. Environ. Res. 8:113-120.

Barrow, N.J., G.W. Brümmer, L. Fischer. 2012. Rate of desorption of eight heavy metals from goethite and its implications for understanding the pathways for penetration. Eur. J. Soil Sci. 63: 389-398.

Basta, N., J.A. Ryan, R.L. Chaney. 2005. Trace element chemistry in residual-treated soil: key concepts and metal bioavailability. J. Environ. Qual. 34: 49-63.

Basta, N.T., and S.L. McGowen. 2004. Evaluation of chemical immobilization treatments for reducing heavy metal transport in a smelter-contaminated soil. Environ. Pollut. 127: 73-82.

Bayramoglu, G., B. Altintas, M.Y. Arica . 2009. Adsorption kinetics and thermodynamic parameters of cationic dyes from aqueous solutions by using a new strong cation exchange resin. Chem. Eng. J. 152: 339-346.
Bolan, N., A. Kunhikrishnan, R. Thangarajan, J. Kumpiene, J. Park, T. Makino, M.B. Kirkham, K. Scheckel . 2014. Remediation of heavy metal(loid)s contaminated soils- To mobilize or to immobilize?. J. Hazard. Mater. 266: 141166.

Brown, G.E., Jr., and G.A. Parks. 2001. Sorption of trace elements on mineral surfaces: Modern perspectives from spectroscopic studies, and comments on sorption in the marine environment. Int. Geol. Rev. 43:963-1073.

Contin, M., C. Mondini, L. Leita, P. Zaccheo, L. Crippa, , M. De Nobili. 2008. Immobilization of soil toxic metals by repeated additions of $\mathrm{Fe}(\mathrm{II})$ sulphate addition. Geoderma 147, 133-140.

Davies, N.A., M.E. Hodson, S. Black . 2003. The influence of time on lead toxicity and bioaccumulation determined by the OECD earthworm toxicity test. Environ. Pollut. 121: 55-61.

Day, P.R. 1965. Particle Fraction and Particle Size Analysis. In: Black AC, EvansDD, Ensminger LE, White JL, Clark FE (eds) Methods of soil analysis. Part I. Am. Soc. Agron., Madison, Wisconsin, USA, pp 545- 566.

Elkhatib E.A., A.G. Thabet, M.L.Mohram. 2001.Sorption of Cadmium in Surfactant-Amended Soils. Arid Land Res. Manag. 15:385-394.

Elkhatib, E., M. Moharem , H. Hamadeen. 2019. Low-cost and efficient removal of mercury from contaminated water by novel nanoparticles from water industry waste. Desalin. Water Treat. 144: 79-88.

Elkhatib, E.A. and J.L Hern.1988. Kinetics of phosphorus desorption from Appalachian soils. Soil Sci. 145, 11-19.

Elkhatib, E.A. and M.L. Moharem. 2015. Immobilization of copper, lead, and nickel in two arid soils amended with biosolids: effect of drinking water treatment residuals. J. Soils Sediments 15: 1937-1946.

Elkhatib, E.A., F. Sherif , M. Kandil, A. Mahdy, M. Moharem, A.A. Al-Basri. 2018. Using nanoparticles from water treatment residuals to reduce the mobility and phytoavailability of $\mathrm{Cd}$ and $\mathrm{Pb}$ in biosolid-amended soils. Environ. Geochem. Health: 40 1573-1584.

Elkhatib, E.A., A.M. Mahdy, F.K. Sherif, K.A. Salama. 2015b. Water treatment residual nanoparticles: a novel sorbent for enhanced phosphorus removal from aqueous medium. Curr. Nanosci. 11: 655-668.

Elkhatib, E.A., A.M. Mahdy, K.A. Salama . 2015a. Green synthesis of nanoparticles by milling residues of water treatment. Environ. Chem. Lett. 13: 333-339.

Elkhatib, E.A., G.El-shebiny, and A.M.Balba.1992. Kinetics of lead sorption in calcareous soils. Arid Soil Res. Rehab. 6: 297-310.

Elkhatib, E.A., G.M. Elshebiny, A.M. Balba. 1991. Lead sorption in calcareous soils. Environ. Pollut. 69: 269-276.

Elkhatib, E.A., M.L. Moharem, A. Mahdy, M. Mesalem. 2017. Sorption, release, and forms of mercury in contaminated soils stabilized with water treatment residual nanoparticles. Land Degrad. Develop. 28: 752-76. 
Esakku, S., A. Selvam, J. Kurian, K. Palanivelu. 2005. Assessment of heavy metal species in decomposed municipal solid waste. Chem. Spec. Bioavailab. 17:95102.

Grobelak, A., A. Placek, A. Grosser, B. Singh, M. Kacprzak. 2017. Effects of single sewage sludge application on soil phytoremediation. J. Clean. Prod. 155: 189-197.

Grossl, P.R., D.L. Sparks, C.C. 1994. Ainsworth, Rapid kinetics of $\mathrm{Cu}$ (II) adsorption/desorption on goethite. Environ. Sci. Technol. 28: 1422-1429.

Guo, G., Q. Zhou, L.Q. Ma . 2006. Availability and assessment of fixing additives for the in situ remediation of heavy metal contaminated soils: a review. Environ. Monit. Assess. 116: 513-528.

Han, F. X., A. Banin, G. B. Triplett . 2001. Redistribution of heavy metals in arid-zone soils under a wetting drying cycle soil moisture regime. Soil Sci. 166: 18-28.

Hashimoto Y., H. Matsufuru, M. Takaoka, H. Tanida, T. Sato. 2009. Impacts of chemical amendment and plant growth on lead speciation and enzyme activities in a shooting range soil: an X-ray absorption fine structure investigation. J. Environ. Qual. 38: 1420-1428.

Herzel, H., O. Kruger, L. Hermann, C. Adam. 2015. Sewage sludge ash - A promising secondary phosphorus source for fertilizer production. Sci. Total Environ. 542: 1136-1143.

Hovsepyan, A., J.C.J. Bonzongo . 2009. Aluminum drinking water treatment residuals (Al-WTRs) as sorbent for mercury: implications for soil remediation. J. Hazard. Mater. 164, 73-80.

Kabata-Pendias, A. and H. Pendias. Trace elements in soils and plants. 3rd ed. Taylor \& Francis Group; 2001.

Kacprzak, M., E. Neczaj, K. Fijalkowski, A. Grobelak, A. Grosser, M. Worwąg, A. Rorat, H. Brattebo, A. Almas, B. R. Singh. 2017. Sewage sludge disposal strategies for sustainable development. Environ. Res. 156: 39-46.

Keeney DR (eds) Methods of Soil Analysis. Am. Soc. Agron., Madison, Wisconsin, USA pp, 181-197.

Khodaverdiloo, H., M. Rahmanian, S. Rezapour, S. Ghorbanti Dashtaki, H. Hadi, F.X. Han . 2012 . Effect of wettingdrying cycles on redistribution of lead in some semi-arid zone soils spiked with a lead salt. Pedosphere 22: 304 313.

Kominko, H., K. Gorazda, , Z. Wzorek. 2017. The possibility of organo-mineral fertilizer production from sewage sludge. Waste Biomass Valoriz. 1-11.

Laidler, K.J., .1965. Chemical Kinetics 2nd. Ed. McGraw Hill. New York.

Lindsay, W.L. and W.A. Norvell .1978. Development of a DTPA soil test for zinc, iron, manganese, and copper. Soil Sci. Soc. Am. J. 42:421-428.

Liu, J. C.Q. Duan, Y.N. Zhu, X.H. Zhang, C.X. Wang. 2007. Effect of chemical fertilizers on the fractionation of $\mathrm{Cu}, \mathrm{Cr}$ and $\mathrm{Ni}$ in contaminated soil. Environ. Geol. 52:16011606.
Loukidou M.X., A.I.Zouboulis, T.D.Karapantsios, K.A.Matis. 2004. Equilibrium and Kinetic Modeling of Chromium (VI) Biosorption by Aeromonas Caviae. Colloids and Surfaces A 242: 93-104.

Lu, K., X. Yang, G. Gielen, N. Bolan, Y.S. Ok, N.K. Niazi, S. $\mathrm{Xu}$, Y. Guodong, X. C. Yuan, X, Zhang, D. Liu, Z. Song, X. Liu, H. Wang. 2017. Effect of bamboo and rice straw biochars on the mobility and redistribution of heavy metals $(\mathrm{Cd}, \mathrm{Cu}, \mathrm{Pb}$ and $\mathrm{Zn})$ in contaminated soil. Environ. Manag. 186: 285-292.

Makris, K.C. and W.G. Harris . 2005. Time dependency and irreversibility of water desorption by drinking water treatment residuals: implication for sorption mechanisms. J. Colloid Interf. Sci. 294:151-154.

Makris, K.C., H. El-shall, W.G. Harris, G.A. O,Connor, T.A. Obreza . 2004. Intraparticle phosphorus diffusion in a drinking water treatment residual at room temperatures. J. Colloid Interf. Sci. 277: 417- 424.

Marguí, E., M. Iglesias, F. Camps, L. Sala, M. Hidalgo. 2016. Long-term use of biosolids as organic fertilizers in agricultural soils: potentially toxic elements occurrence and mobility. Environ. Sci. Pollut. Res. 23: 4454-4464.

McBride, M.B. 1994. Environmental Chemistry of Soils. Oxford Univ. Press, New York. 406 pp.

McLaughlin, M. J., M. Whatmuff, M. Warne, D. Heemsbergen, G. Barry, M. Bell, D. Nash, D. Pritchard. 2006. A field investigation of solubility and food chain accumulation of biosolid-cadmium across diverse soil types. Environ. Chem. 3, 428-432.

Moharem, M. L. 2016. Solubility and availability of heavy metals in soils as affected by compost amendment. Alex. Sci. Exch. J. 37:36-44.

Moharem, M. L., H.A.S. Mitwally, M. Rashad, E.A. Shalaby, A. Morsy. 2016. Availability and uptake of cadmium, copper, and zinc by radish plant grown on contaminated soils as affected by compost amendment. Alex. Sci. Exch. J. 37: 151-164.

Moharem, M., E. Elkhatib, M. Mesalem. 2019. Remediation of chromium and mercury polluted calcareous soils using nanoparticles: Sorption-desorption kinetics, speciation and fractionation. Environ. Res. 170: 366-373.

Moharem, M.L. 2012. Reducing heavy metals risks in AbuRwash polluted soil using drinking water treatment residuals. The Egypt. Sci. Mag.7: $92-100$.

Moharem, M.L., E.A. Elkhatib, M.H. Elgammal. 2013. Reducing copper availability in contaminated soils using drinking water treatment residuals. Soil Sediment Contam. 22:595-613.

Moharem, M.L., T.M. Omar, and H.M. Gaber. 2011. Immobilization of heavy metals in contaminated sites using natural organic materials. Alex. J. Agric. Res. 56:103-115

Moral, R., R.J. Gilkes, M.M. Jordan. 2005. Distribution of heavy metals in calcareous and non-calcareous soils in Spain. Water Air Soil Poll. 162: 127-142. 
Narwal, R.P., B.R. Singh, B. Selbu. 1999. Association of cadmium, zinc, copper. and nickel with components in naturally heavy metal rich soils studied by parallel and sequential extraction. Commun Soil Sci. Plan. 30:12091230 .

Nelson DW, L.E. Sommers .1982. Total carbon, organic carbon and organic matter. In: Page AL, Miller RH, Keeney DR (eds) Methods of soil analysis. Am. Soc. of Agron., Madison,Wisconsin, USA, pp 539-549.

Nelson, R.E. 1982. Carbonate and Gypsum. In: Page AL, Miller RH, Keeney DR (eds) Methods of soil analysis. Am. Soc. of Agron., Madison,Wisconsin, USA, pp 181197

Phillips, I. and L. Chapple .1995. Assessment of heavy metals contaminated site using sequential extraction, TCLP and risk assessment techniques. J. Soil Cont. 4:311-325.

Ponizovskii, A.A, E.V. Mironenko. 2001. Mechanisms of lead (III) sorption in soils. Euras Soil Sci. 34:371-381.

Ponizovsky, A., H.E. Allen, A.J. Ackerman. 2007. Copper activity in soil solutions of calcareous soils. Environ. Pollut. 145:1-6.

Qian, X., C. Fang, M. Huang, V. Achal. 2017. Characterization of fungal-mediated carbonate precipitation in the biomineralization of chromate and lead from an aqueous solution and soil. J. Clean. Prod. 164, 198-208

Rhoades, J.D. 1982. Cation Exchange Capacity. In: Page et al (eds) Methods of Soil Analysis, part II: Chemical and Microbiological Properties, 2nd edn. SSSA, Madison.

Richards, L.A. 1954. Diagnosis and improvement of alkaline soils. USDA Handbook 60. US Government Printing Office, Washington, pp 102-105.

Rigby, H., B. O. Clarke, D. L. Pritchard, B. Meehan, F. Beshah, R. Smith, N. A. Porter. 2015. A critical review of nitrogen mineralization in biosolids-amended soil, the associated fertilizer value for crop production and potential for emissions to the environment. Sci. Total Environ. 541: 1310-1338.

Ross, G.J., C. Wang .1993. Acid ammoniumoxalate method. In: Carter MR (ed) Soil sampling and methods of analysis. Lewis Publishers, Boca Raton, pp 239-246.

Sancar, J., R. Milacic, , M. Strazar, , O. Burica. 2000. Total metal concentrations and partitioning of $\mathrm{Cd} \mathrm{Cr}, \mathrm{Cu}, \mathrm{Fe}, \mathrm{Ni}$, and $\mathrm{Zn}$ in sewage sludge. Sci. Total Environ. 250: 9-19.

Sánchez-Martín, M.J., M. García-Delgado, L.F. Lorenzo, M.S. Rodríguez-Cruz, M. Arienzo. 2007. Heavy metals in sewage sludge amended soils determined by sequential extractions as a function of incubation time of soils. Geoderma 142: 262-273.

Sarkar, D., K.C. Makris, V. Vandanapu, R. Datta . 2007. Arsenic immobilization in soils amended with drinkingwater treatment residuals. Environ. Pollut. 146: 414-419.

Schwertmann, U. and R.M. Taylor. 1989. Iron oxides, In: Dixon, J.B., Weed, B. (Eds.), Minerals in Soil Environments. second ed. Soil Sci. Soc. Am., Madison, WI, pp. 379-438.
Shao, J. G., X. Z. Yuan, L. J. Leng, H. J. Huang, L. B. Jiang, H. Wang, X. H. Chen, G. M. Zeng. 2015. The comparison of the migration and transformation behavior of heavy metals during pyrolysis and liquefaction of municipal sewage sludge, paper mill sludge, and slaughterhouse sludge. Bioresource Technol. 198: 16-22.

Shrivastava, S.K., D.K. Banerjee.1998. Operationally determined speciation of copper and zinc in sewage sludge. Chem. Spec. Bioavailab. 10: 137-143.

Singh, R.P., M. Agrawal. 2008. Potential benefits and risks of land application of sewage sludge. Waste Manage. 28: 347-358.

Skene, T.M., J.M. Oades, G. Kilmore .1995. Water treatment sludge: a potential plant growth medium. Soil Use Manage. 11:29-33.

Smith, S.R. 1996. Factors influencing the bioavailability of PTEs to crop plants. In: Agricultural recycling of sewage sludge and the environment. Wallingford: CAB International,:59-85.

Sparks, D.L. 2001. Elucidating the fundamental chemistry of soils: past and recent achievements and future frontiers. Geoderma 100: 303-319.

Sparks, D.L. 2003. Environmental Soil Chemistry. 2nd. Ed. Academic Press, New York.

Sposito, G. 1989. The Chemistry of Soils. New York: Oxford University Press.

Tessier, A., P.G.C. Campbell, M. Bisson.1979. Sequential extraction procedure for the speciation of particulate trace metals. Anal. Chem. 51: 844-851.

Tisdale, S.L., W.L. Nelson, and J.D. Beaton.1985. Soil Fertility and Fertilizers.4th ed. Macmillan, New York.

Turkdogan, M.K., F. Kilcel, K. Kara, I. Tuncer, , I. Uygai. 2003. Heavy metals in soil, vegetables and fruits in the endemic upper gastrointestinal cancer region of Turkey. Environ. Toxicol. Pharm. 13: 175-179.

Ure, A.M. 1995. Methods of Soil Analysis for Heavy Metals in Soils. In: Alloway BJ (ed) Heavy metals in soils, 2nd ed. Blackie Academic and Professional, London, pp 5895.

Wang, Q.R., Y.S. Cui, X.M. Liu, Y.T. Dong, P. Christe. 2003. Soil contamination and plant uptake of heavy metals at polluted sites in China. J. Environ. Sci. Heal. A 38, 823-838.

Wang, X., T. Sato, B. Xing, S. Tao. 2005. Health risks of heavy metals to the general public in Tianjin, China via consumption of vegetables and fish. Sci. Total Environ. 350:28-37.

Weber, J.W.J. and J.C. Morriss. 1963. Kinetics of adsorption on carbon from solution. J. Sanit. Eng. Div., Am. Soc. Civil Eng. 89: 31-60.

Wong, J.W.C., 1995. The production of artificial soil mix from coal fly ash and sewage sludge. Environ. Technol. 16: 741-751.

Wu, S.C., Y.M. Luo, K.C. Cheung, M.H.Wong . 2006. Influence of bacteria on $\mathrm{Pb}$ and $\mathrm{Zn}$ speciation, mobility and bioavailability in soil: a laboratory study. Environ. Pollut. 144: 765-773. 
Yang, B., Y. Cao, J. Ren, M. Wang, H. Luo, F. Li . 2019.

Water incubation-induced fluctuating release of heavy metals in two smelter-contaminated soils. J. Environ. Sci. 82: $14-23$
Zheng, S.A., M.K. Zhang . 2011. Effect of moisture regime on the redistribution of heavy metals in paddy soil. J. Environ. Sci. 23: 434-443.

Zhou, L.X. and J.W.C Wong. 2001. Effect of dissolved organic matter from sludge and sludge compost on soil copper sorption. J. Environ. Qual. 30: 878-883.

\title{
الملخص العريي
}

اعادة التوزيع وحركية التحرر لبعض العناصر الثقيلة فى الأراضى المعامله بالحمأه والمضاف إليها مخلفات

\section{معالجة مياه الثرب النانومتريه}

\author{
محمد لطفي محرم
}

العناصر الى صورة أقل ثباتا فى مكونات التربه وأكثر صلاحيه للامتصاص بواسطة النبات وكان هذا التأثير أكثر وضوحا فى عنصر النحاس فى الاراضى الرمليه وأقل تأثنرا فى عنصر النيكل.

-إضافة مخلفات معالجة مياه الثرب النانومتريه إلى الاراضى الجيريه والاراضى الرمليه أدى إلى زياده معنويه فى صور العناصر الاكثر ثباتا فى التربه والاقل صلاحيه للامتصاص بواسطة النبات مع زيادة هذا التأثير بزيادة مدة التحضين وبالاضافه الى ذلك حدث إنخفاض ملحوظ فى كمية العنصر المتحرر بمستخلص DTPA(المعبر عن صلاحية العنصر للامتصاص بواسطة النبات) خلال الخمس دورات من الابتلال والتجفيف كنتيجه لاضافة مخلفات معالجة مياه الثرب النانومتريه.

تشيرالنتائج النهائيه إلى إمكانية إستخدام هذه المخلفات النانومتريه للتقليل من الأثار الضاره للعناصر الثقيله فى إلى التهيل الاراضى المعامله بالحمأه، لذا فهذه الدراسه توصى بخلط الحماءه مع مخلفات معالجة مياه الشرب النانومتريه عند الاستخدام فى الاراضى المختلفه.
أجريت هذه الدراسه لبيان تأثير مخلفات معالجة مياه

الثرب النانومتريه (المتحصل عليها من محطات تتقية مياه الثرب والتى تم تحويلها معمليا إلى مواد نانومتريه عن طريق عملية الطحن) وذللك عند ثناث مستويات إضافة (صفر، \% (, •،\%, • •) لنوعين من الأراضى المصريةً

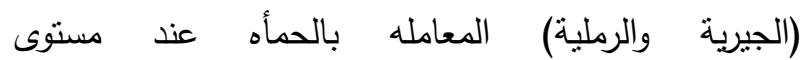
إضافة(\% r, •)على التغير فى صورة العنصر (مدى أرتباط العنصر بمكونات التربه المختلفه) محلى الدراسه (النحاس،الرصاص،النيكل) وكذلك على تحرر هذه العناصر إلى المحلول المائى للتربه .هذه الاراضى المعامله بالحمأه والمضاف إليها مخلفات معالجة مياه الشرب النانومتريه تم تحضينها لمدة ستين يوما على خمس دورات منتاليه من الابتالال والتجفيف كل دوره إثثى عشر يوما وذللك لبيان تأثير

$$
\text { زمن التحضين على صورة العنصر وذائييته. }
$$

$$
\text { أوضحث نتائج الدراسه الاتى: }
$$

- زيادة فترة التحضين من ثلاثين الى سنين يوما للاراضى المعامله بالحمأه والغير مضاف اليها مخلفات معالجة مياه الشرب (الكنترول) أدى الى تغير واضح فى تحويل صور 